\title{
Financial reporting, tax, and real decisions: toward a unifying framework
}

\author{
Douglas A. Shackelford • Joel Slemrod • \\ James M. Sallee
}

Published online: 6 May 2011

(C) Springer Science+Business Media, LLC 2011

\begin{abstract}
This paper provides a first step toward joint evaluation of taxation and financial reporting in the standard economic analyses of corporate behavior. It develops a framework that formalizes the idea that the attractiveness of some investment decisions is enhanced because they provide managers with discretion over the timing of taxable income and/or book income. It then examines from this perspective several current examples of tax and accounting issues.
\end{abstract}

Keywords Taxation · Accounting · Corporate behavior · Discretion

JEL Classification $\mathrm{H} 25 \cdot \mathrm{N} 41$

\section{Introduction}

Contrary to the standard assumption of economic analysis, public corporations care not only about the expected present value of their after-tax cash flows, but also about how the transactions that give rise to these cash flows are depicted in their financial accounts (using either accrual or cash flow accounting methods). ${ }^{1}$ In this paper, we provide a framework that unifies financial reporting, tax, and real choices by introducing financial reporting considerations into a standard economics model of optimal,

\footnotetext{
${ }^{1}$ We discuss the evidence supporting this claim below.

D.A. Shackelford

University of North Carolina, Chapel Hill, NC, USA

J. Slemrod $(\varangle)$

University of Michigan, Ann Arbor, MI, USA

e-mail: jslemrod@umich.edu

J.M. Sallee

University of Chicago, Chicago, IL, USA
} 
after-tax investment decisions. We view this as a first step toward joint evaluation of taxation and financial reporting in an optimizing model of corporate behavior. Ideally, it also provides a common language for a broad audience of both accountants and economists.

The framework developed in this paper formalizes the idea that the attractiveness of some real decisions is enhanced because they provide managers with discretion over the timing of taxable income and/or book income. Thus, to the extent managers value flexibility in their tax and financial reporting, they are more likely to make real decisions that provide discretion. We present and discuss several examples that are consistent with our framework.

The paper proceeds in the following manner. To motivate the model, Sect. 2 provides some background about financial accounting and the differences between how income and income tax are reported to the tax authority and to the investing public, and summarizes the evidence that accounting matters for firm valuation and decisions. Section 3 discusses several examples of the interaction between financial accounting considerations and real decisions. In Sect. 4, we present our model, which is intended to provide a common framework, as well as a common vocabulary, for economists and accountants to discuss the effect of taxation. Sections 5 and 6 draw out the implications of the model for real and accounting decisions, respectively. We discuss the implications for policy and research in Sect. 7 and offer concluding remarks in Sect. 8.

\section{Accounting and taxation of corporations}

\subsection{How it works}

Publicly-held US companies have to provide financial information to at least two different audiences, each of whom has a stake in assessing how much income is being generated. One is a public accounting to the firm's stakeholders: investors, creditors, customers, suppliers, employees, regulators, and rating services, among others. The other is a nonpublic accounting to the taxing authorities, such as the United States' Internal Revenue Service (IRS).

The IRS can see the public financial statements, which helps the IRS to better detect any understatement of taxable income. In recent years, the value of seeing the public financial statements has been enhanced by the Schedule M-3 of the tax return, which requires the company to provide detailed information that reconciles the information on the financial statements to the information on the tax return. Although investors cannot see the tax return and firms are not required to disclose specific information from the tax return, e.g., taxable income, investors receive some information about taxes in the financial statements. This information in the financial statements may be informative to both the IRS and investors. For example, FASB Interpretation No. 48 (FIN 48), which requires firms to disclose the portion of their recognized tax benefits (for book purposes) that they do not expect to retain if audited, provides investors with information about the firm's tax risk and potentially aids the IRS in 
identifying firms for audit (see FIN 48 analyses in Mills et al. 2010; Frischmann et al. 2008; Blouin et al. 2007 among others). ${ }^{2}$

Firms report a different measure of income to each audience. The income reported in financial reports may differ from taxable income for at least three reasons. First, there are explicit differences in the intent of the two reports. Financial statements are designed to reduce information asymmetries through reliable and relevant disclosures. The tax return reflects policy that balances (often competing) economic objectives of revenue collection, equity, efficiency, and simplicity as well as political objectives to reward favored constituencies. Given the differences in the purposes of the financial statements and the tax return, it is not surprising that the most useful measure of a firm's profitability for shareholders usually differs from the most useful measure of profitability for the taxing authorities.

A second reason why book income and taxable income may differ is that while financial accounting strives to record the underlying economics of a transaction in an objective and verifiable way, much of the tax system is designed to induce or reward particular behavior. For example, for book purposes, the value of the firm's equipment is depreciated (an expense that reduces book income) each period based on estimates of the equipment's deterioration. For tax purposes, the value of the firm's equipment is depreciated (a deduction that reduces taxable income) each period by a statutorily determined (without regard to actual deterioration) amount, which may be intentionally altered by legislation to encourage acquisition of equipment. Because the statutory depreciation for tax purposes rarely equals the estimate for financial reporting of the equipment's actual deterioration, book income and taxable income will differ.

A third reason why book income and taxable income may differ is that there are incentives to mislead both the audience for the financial statements and the audience for the tax return (e.g., the IRS) about ongoing operations. Both the financial statement and the tax return are snapshots of what the corporation wants some audience-either the investing public or the IRS — to see. For example, in a given year, managers may have incentives to look more profitable (see Healy and Wahlen 1999 for a review of studies documenting manipulation of the financial reports). Returning to the depreciation example, because determining deterioration is an imprecise process, managers have some leeway in recording book depreciation. Thus, book depreciation becomes a means of managing book earnings, further creating differences in the two measures of income.

Both the IRS and the US Securities and Exchange Commission (SEC), which regulates public financial disclosures in the US, have safeguards to protect against misleading reports. To ensure that it is receiving its appropriate share of profits, the IRS receives millions of confidential-albeit potentially misleading-reports from businesses about their earnings. Audit decisions are based on comparisons of tax

\footnotetext{
${ }^{2}$ FIN 48 disclosures will become even more useful for the IRS, going forward. In April 2010, the IRS released in draft Form UTP (Uncertain Tax Position Statement), which will require corporations to report concise descriptions about the federal income tax positions for which they have recorded reserves under FIN 48 in its audited financial statements.
} 
returns across time for the same taxpayer, across similar taxpayers in the same year, and with the information in the firm's financial statements. ${ }^{3}$

On the book side, the SEC receives financial statements from all publicly-traded corporations. The financial statements must conform to US Generally Accepted Accounting Principles (GAAP). Penalties for failure to comply include restating prior statements, losing access to the public capital markets, and criminal proceedings against managers.

Finally, several recent studies document that book-tax divergence can be costly, increasing both tax payments and financial reporting costs (see review in Graham et al. 2011). Mills (1998) provides an example of increased tax costs arising from book-tax divergence. She uses confidential IRS data to demonstrate that firms with larger differences between book earnings and taxable income are more likely to be audited by the IRS. Hanlon (2005) provides an example of increased financial reporting costs arising from book-tax divergence. Using financial statement disclosures, she finds that the more book income and taxable income diverge, the more investors trade as though they consider the book earnings to be of lower "quality" (i.e., unlikely to persist).

\subsection{Why it matters}

Over the last 40 years, the primary accounting research questions have concerned which accounting information matters, why and for whom it matters, and how it affects other economic choices. ${ }^{4}$ A recurring question in the literature is: to what extent will firms expend resources to mitigate financial reporting costs? ${ }^{5}$ This question has been explored in numerous settings. Sometimes managers appear willing to expend nontrivial amounts of cash for "better" accounting numbers; in other settings, the financial accounting information appears to be of second order.

Several of these studies have explored whether firms will remit more taxes, if it enables them to report better accounting earnings. To demonstrate that firms are (occasionally) willing to remit higher taxes in order to achieve certain financial accounting goals, we briefly review book-tax tradeoffs in fraud allegations, equity-debt exchanges, debt covenants, inventory, and employee compensation. For a more extensive review of this literature, see Shackelford and Shevlin (2001) and Hanlon and Heitzman (2010).

\footnotetext{
${ }^{3}$ Numerous IRS documents, both publicly available and confidential, detail the role that a firm's financial statements should play in the decision to audit and in the examination of a firm's tax return. Some publicly available directives, such as LMSB-04-0507-044 and LMSB Guide for Quality Examinations, concern the general role of the financial statements in the overall auditing process. Other publicly available documents, such as Rev. Proc. 2007-53 and Rev. Proc. 2005-99, specify accounts in the financial statements that are to be used by the examiner. We appreciate an anonymous referee's suggestion that we provide detailed confirmation that the IRS uses the financial statements in their auditing process.

${ }^{4}$ See extensive reviews in Kothari (2001); Dechow et al. (2010); Armstrong et al. (2010); and Beyer et al. (2010).

${ }^{5}$ Financial reporting costs may be real or perceived and can pertain to income, shareholders' equity, or any other financial accounting disclosures; however, typically scholars and the capital markets focus on the costs associated with reporting lower-than-expected book income.
} 
Erickson et al. (2004) report that firms pay taxes on fraudulent profits, presumably to reduce the likelihood of their financial statements being identified as fraudulent. They examine 27 firms that restated their financial statements because of SEC allegations of accounting fraud from 1996 to 2002. Allegations include reporting nonexistent and false revenues, recording fake inventory, and undertaking fraudulent schemes to inflate assets, revenues, and net income. The average firm in their study overstated earnings by $\$ 125$ million and paid taxes on those profits of $\$ 12$ million, equal to $1.3 \%$ of the average firm's market value in the year prior to earnings overstatement. The income taxes paid per dollar of overstated earnings averaged $\$ 0.11$, and the total amount of taxes paid on overstated earnings by all firms in the sample was approximately $\$ 320$ million on overstated earnings of $\$ 3.36$ billion.

Similarly, Dyreng (2009) finds that, as firms approach debt covenant violation, they make financial reporting choices that result in higher book profits. As with the fraudulent earnings, they pay taxes on these inflated profits. In other words, managers accept the higher tax liability that comes with the higher book income in order to avoid the costs associated with violating debt covenants. Dyreng (2009) estimates that the additional taxes equal an increased cost of debt financing of between 13 and 23 basis points, on average.

Another setting where firms have been shown to opt for higher accounting profits at the cost of higher taxes is compensation. Companies can deduct from taxable income the difference between the fair market value and the strike price for nonqualified stock options, but cannot deduct any costs associated with incentive stock options. Matsunaga et al. (1992) find that few firms choose to disqualify their incentive stock options (converting them into nonqualified stock options) even when doing so would lower their tax liability. The reason is that disqualification also results in a charge to earnings. Examining firms after the Tax Reform Act of 1986, they estimate that those that did not qualify avoided a $2.3 \%$ reduction in reported earnings at a cost of \$0.6 million, on average. Francis and Reiter (1987) find similar book-tax tradeoffs with pensions.

Engel et al. (1999) estimate how much cost firms are willing to incur simply to give the appearance of a better balance sheet. They study trust preferred stock (TRUPS), which is not treated as debt for financial accounting even though its dividends are deductible for tax purposes. They find that the 44 firms that issued TRUPS and retired debt from 1993 to 1996 reduced their debt/asset ratio by $13 \%$ at a cost of \$10-43 million, on average, in issuance and retirement costs. As further quantification of the cost of a better balance sheet, in their study of corporate divestitures, Maydew et al. (1999) show that financial reporting incentives and cash constraints led many firms to incur tax liability related to the sale of companies, rather than opt for tax-free spin-offs.

Finally, an extensive literature shows that firms choose inventory cost methods that result in higher taxes (see review in Shackelford and Shevlin 2001). In inflationary times, last-in first-out (LIFO) inventory accounting minimizes the tax liability because it assigns the most recent costs ("last-in") to the newly produced ("first-out") goods. Nonetheless, even during inflationary periods, LIFO has never been widely adopted. The reason is that firms using LIFO for tax purposes also must use it for book purposes, where the same matching results in lower accounting profits. In other 
words, inventory costing choices are consistent with most firms preferring high accounting profits as opposed to lower taxes.

These and other corporate choices make clear that managers often opt for higher book earnings at the cost of increased taxes. Stated differently, many firms will not implement tax plans that lower cash taxes paid, if they also reduce the reported accounting profits.

Another large literature in accounting attempts to understand why firms place such heavy reliance on reported book profits. Three explanations dominate the literature. First, accounting earnings represent the economics of transactions better than cash flows do. For example, accrual-based accounting earnings have more predictive ability than do cash flows. Specifically, current book earnings predict future cash flows better than current cash flows do, and they also predict future book earnings better than current cash flows do. Second, facing asymmetric information, investors have limited access to reliable information about the firm other than its audited, public financial statements. Thus, managers believe that the accounting information, particularly book income, is the primary determinant of the capital market's assessment of the firm's performance and is more important than cash flow. Third, many contracts rely heavily on accounting figures. Thus, even in privately-held firms, accounting information can play a key role in compensation, bank loans, labor contracts and other important contracting relations. Not surprisingly, if the contracts are based on financial accounting information, managers are apt to manage the books to maximize their utility. For example, Healy (1985) finds that executives rewarded by accountingearnings-based bonuses make financial reporting choices that increase their compensation

\section{Examples of the value of discretion}

This section provides examples that illustrate how taxes affect real and accounting choices. In each case, we see the value created by a real decision that provides book and/or tax discretion. We also see that firms that value discretion, at the margin, will have incentives to make real decisions that increase their flexibility in reporting for both book and tax purposes. In the first example, the decision to operate in a lowtax country provides book discretion. In the second example, activities that result in uncertain tax positions (e.g., the transfer prices of intercompany sales) create book discretion. In the third example, risky investments provide book discretion. In the fourth example, incentives to increase book and tax discretion encourage firms to extend more credit than would otherwise be optimal. In the final example, firms have an incentive to hold larger amounts of inventory than would otherwise be optimal in order to preserve the book and tax discretion available with the last-in, first-out (LIFO) inventory costing method.

\subsection{Incentives to invest abroad}

The first example of the value of discretion involves the incentive to invest outside the US. Although foreign subsidiaries of US companies pay income tax in the jurisdictions where they operate, their parent companies generally do not pay any US taxes 
on these foreign earnings until the profits are repatriated as dividends, at which time they pay the US tax due net of any applicable foreign tax credit for taxes paid to the foreign government (sometimes called the "residual" US tax). If the profits are never repatriated, no US taxes are ever paid.

For book purposes, firms must record the profits of their foreign subsidiaries in the period when they are earned. ${ }^{6}$ However, under APB 23, managers have a choice about when to record the book tax provision related to the US tax triggered by repatriation. One option is to estimate the eventual US tax and expense those taxes when the foreign profits are booked. By matching the tax provision to the foreign earnings, this option lowers current after-tax earnings, but leaves after-tax earnings unaffected when the dividend is paid.

If the firm does not expect to repatriate the profits in the foreseeable future, there is a second option. The firm can defer the expense until they decide to repatriate the funds. If they never repatriate, then they never provide for the US taxes. This approach results in higher after-tax earnings in the year that the foreign profits are earned (because profits are not reduced by an estimate of the US taxes at repatriation). It also results in a higher book tax provision (and lower after-tax book earnings) in the period when the firm decides to repatriate the foreign profits.

Because a firm can change its intentions about paying a dividend at any time, it has the potential to shift some book income over time. Furthermore, a firm may decide that profits whose US tax provision has already been booked will not be repatriated after all. If so, the tax expense that was booked for the US tax in the past is removed from the books, shifting after-tax book income into that year.

This discretion in financial reporting provided by foreign operations provides firms with an (additional) incentive to locate in low-tax countries, e.g., tax havens. The reason is that generally the less the foreign tax, the greater the US tax, and thus the larger the book tax provision that can be shifted across periods. Thus, GAAP encourages investment in tax havens.

To summarize, the tax policy of deferring the US tax liability on the earnings of foreign subsidiaries provides the parent company with potentially valuable discretion in financial reporting. Because the US tax payment is deferred until repatriation, firms can expense the tax when the profits are earned or whenever they decide that they will repatriate the funds. This discretion provides an incentive to invest in low-tax countries. The discretion would be eliminated if a territorial system was adopted, or as President Obama has suggested, deferral of the residual US tax was repealed. In fact, the strong opposition by many US multinationals to eliminating deferral may be based as much on the loss of flexibility in the reporting of the book-tax expense as on the impact on cash taxes paid (Graham et al., 2009). ${ }^{7}$

In 2004, the book discretion arising from the tax law came full circle. The American Jobs Creation Act of 2004 provided a tax holiday to US companies that repa-

\footnotetext{
${ }^{6} \mathrm{An}$ important distinction between book and tax is that the financial statements include the activities of all foreign subsidiaries, while the tax return generally excludes the profits of foreign subsidiaries.

${ }^{7}$ Referring to the possible loss of discretion in recording the residual US tax if deferral were eliminated, Ralph Helmann, the lead lobbyist for the Information Technology Industry Council stated, "It's probably the top issue right now for the tech community. This one hits the bottom line of companies more than any other issue right now. We have to defeat it" (Drucker 2009).
} 
triated earnings from their foreign subsidiaries. The amount of foreign earnings that enjoyed a reduced tax rate was limited by the amount of "permanently reinvested foreign earnings," an accounting term for the amount of profits in foreign subsidiaries for which the firm has not recorded a residual US book tax provision. In other words, the benefit of the tax holiday was affected by the way that the managers booked the tax law's deferral of US taxes.

This example demonstrates the intersection and joint determination of a real decision (where to locate operations), a tax and financial decision (when to repatriate), and a book decision (when to record the book tax provision related to the repatriation). By investing abroad, the firm gains valuable tax and book discretion. By timing the repatriation, the firm gains valuable tax and book discretion (as well). ${ }^{8}$

The model of Sect. 4 below formalizes the idea that the incremental discretion in the timing of the book tax provision provides an incentive for some firms to invest in low-tax countries. The lower the foreign tax rate, the larger the residual tax in the US, and consequently the greater the earnings management potential. Although the richness of this setting has long existed (see Collins et al. 2001, and Krull 2004 for early studies), the 2004 tax holiday has led to a flurry of empirical studies regarding the book, tax, and real effects of deferral (see Faulkender and Petersen 2009; Blouin and Krull 2009; and Dharmapala et al. 2009, among others). Of these recent studies, none demonstrates the unifying framework developed in this paper better than the Graham et al. (2009) survey of tax executives. They report that the ability to defer the income tax expense on the earnings of subsidiaries affects both the location of operations and the decision whether to reinvest or repatriate those earnings. In fact, they find that managers value the financial reporting benefits of deferral as much as the cash taxes saved under deferral. Blouin et al. (2009) add that firms that elect APB 23 are less likely to repatriate because dividends from foreign subsidiaries trigger income tax expense without any book earnings. These findings corroborate our own private discussions with managers, who stress that both financial reporting and taxes are important factors in business location decisions. In short, the deferral under the tax law, the financial reporting requirements under GAAP, and the real decision about where to conduct business are comingled. To examine any part of this jointly determined decision and ignore the other factors may result in erroneous inferences about the factors driving business locations, tax decisions and reporting choices.

\subsection{Incentives to engage in transfer pricing}

The second example of discretion involves uncertain tax positions that give rise to book discretion. Although many transactions involve legal and factual ambiguity, we focus on intercompany transfer pricing within a multinational corporation. As noted above, financial statements are reported on a worldwide consolidated basis, but tax returns generally exclude profits earned through foreign subsidiaries. Thus,

\footnotetext{
${ }^{8}$ If estimable, firms are required to disclose an estimate of the US taxes that would be paid, if the foreign earnings were repatriated. Collins et al. (2001) show that investors incorporate this estimate of residual US taxes, implying that classifying foreign earnings as permanently reinvested is not costless. However, they add that most firms claim the residual US taxes are not estimable. Thus, no amount of taxes is reported.
} 
multinationals can lower worldwide taxes by strategically setting their intercompany transfer prices, for example, by having corporations located in high-tax countries buy at a high price and sell at a low price when trading with affiliated corporations in low-tax countries.

Taxing authorities in high-tax countries attempt to defend their tax bases by establishing transfer pricing rules that constrain this type of cross-country income shifting, and there is a continual cat-and-mouse game between multinationals and the taxing authorities over transfer pricing. The most difficult transfer prices involve intangibles whose value is difficult to establish (e.g., brand names) and (whose taxable income) can be easily shifted. Thus, tax minimization opportunities for transfer pricing are greatest among multinationals with high profit margins from intangibles, e.g., research and development. The classic example is the pharmaceutical industry.

The tax uncertainties associated with these companies provides some book discretion. Since transfer prices are very difficult to establish and are subject to continual scrutiny by taxing authorities around the globe, it is very difficult to estimate the eventual worldwide taxes that will be paid following possible audits in multiple jurisdictions. Thus, companies typically accrue a liability for the uncertainty surrounding transfer prices. Over time, resolution is reached about the tax liability, albeit sometimes years later. In the meantime, the uncertainty surrounding the eventual resolution of the tax liability gives the company some leeway in estimating its book tax provision. This is sometimes referred to as "cushion." Historically, it has been viewed as an important means of managing earnings (Dhaliwal et al. 2004; Blouin and Tuna 2006), i.e., shifting earnings across accounting periods.

To summarize, engaging in transactions that inherently result in uncertainty about the tax liability provides not only tax discretion (e.g., the ability to use transfer prices to shift income from high-tax countries to low-tax countries), but also provides book discretion. Investments in intangibles that can cross jurisdictions carry the added benefit of facilitating both tax and earnings management.

\subsection{Incentives to hold risky assets}

The third example of discretion involves risky assets and how they can enable a firm to lower its book tax provision, boosting total assets and equity. Differences in the book and tax bases of assets and liabilities result in deferred tax assets and liabilities. The largest source of deferred tax assets is net operating loss carryforwards, which have been expensed for book purposes but not yet deducted for tax purposes (Raedy et al. 2010). When losses occur, firms can book the future tax savings that they will receive when their net operating loss carryforwards are used to offset income in the future as an asset. However, if there is uncertainty about whether the carryforwards will ever be used, the firms must reduce the reported asset by a valuation allowance. Therefore, the net deferred tax asset (deferred tax asset less valuation allowance) is the amount expected to actually offset income in the future.

To the extent firms can reasonably expect taxable income in the future, they are not required to book a valuation allowance. This has the effect of lowering the book tax provision, increasing the deferred tax asset, and thus increasing shareholders' equity. By investing in risky assets with higher expected yields, firms that on average expect 
losses increase the probability of generating taxable income in the future. Thus, risky assets provide discretion in the recording of the valuation allowance.

This incentive to hold high-yield risky assets is particularly relevant for banks and insurers because the rules governing regulatory capital are stricter than those for GAAP. In fact, for regulatory capital purposes, banks (life insurance companies) can only count as capital expected future taxable income if it is projected to be realized within the next 12 (36) months. This provides an incentive for banks and insurers to hold a riskier portfolio than would otherwise be optimal because risky assets have higher yields, increasing the potential for higher taxable income, enabling the financial institution to lower its book tax provision. This incentive to hold high-yield, risky assets has become far more important since the financial crisis left many companies with very large net operating loss carryforwards. Those banks and insurers with the largest losses during the financial crisis have the greatest incentives to hold the riskiest portfolios, going forward, because risky assets give them the ability to reduce their book tax provision. 9

\subsection{Incentives to extend credit}

The next example of the value of discretion involves incentives to extend credit. Consider a firm with $\$ X$ in cash sales and $\$ Y$ in credit sales. Further assume that, after considering that some of the credit sales will not be collected, collection costs and the time value of money, the present value of the $\$ Y$ of credit sales equals $\$ X$. That is, the expected present value of the credit sales equals the value of the cash sales.

If the firm would benefit from the ability to manage its earnings, then the discretion provided by the credit sales makes them more valuable to the firm than the cash sales. The reason is that, at the time of the sale, the firm must estimate the uncollectible receivables and accrue (i.e., report as a current expense) the anticipated bad debts. Because estimates are, by definition, imprecise, firms have some leeway in the amount that they record for bad debts. If they wish to shift some income to (from) this year from (to) future years, they can lower (increase) the estimate of bad debts this year, within reason, and then record higher (lower) bad debt expenses in future years. Moreover, if the firm would benefit from the ability to manage its taxable income, then the discretion provided by a dollar of credit sales again makes it more valuable for tax purposes to the firm than a dollar of cash sales. The reason is that firms cannot deduct their bad debts at the time of the sale. Instead, they must wait until a specific receivable is deemed worthless. However, determining when a receivable becomes worthless is a judgment call. This element of judgment provides the taxpayer with valuable discretion in the timing of the deduction, i.e., credit sales provide the firm some leeway in recording a tax deduction. Investments that produce write-offs generate discretion in the timing of real taxes. Because credit sales provide potentially important discretion in recording transactions for book and tax purposes,

\footnotetext{
${ }^{9}$ For example, at December 31, 2009, Citigroup had deferred tax assets (net of deferred tax liabilities) of $\$ 46$ billion. Their valuation allowance for GAAP purposes was zero, but $\$ 26$ billion were disallowed for tier 1 regulatory capital purposes. Bank of America had net deferred tax assets of $\$ 27$ billion, a valuation allowance of $\$ 4$ billion and another $\$ 7$ billion disallowed for tier 1 regulatory capital purposes.
} 
we would anticipate that some firms would advance credit at a lower cost than would be otherwise optimal.

In addition to the usual incentive to accelerate deductions for tax purposes, the tax discretion provided by credit sales may be valuable when net operating losses or credits are expiring. Loss or credit expiration is a reason why marginal tax rates may vary across periods. To the extent that write-offs are associated with unprofitable ventures (e.g., a firm's profitability is inversely correlated with bad debts), this discretion is ex ante particularly valuable, because it reduces the probability of being in a net operating loss position. By timing the write-offs of receivables, the company may be able to maximize the tax savings from both operational losses and write-offs; they also gain discretion in the recognition of book income. Because the timing for tax and book purposes must be the same, the value of discretion depends on the value to the firm of loosening the constraint on both types of shifting. The added discretion implies that high-risk ventures (e.g., banks lending to developing countries) are more attractive than otherwise for those companies for which either tax and/or book discretion has value. ${ }^{10}$

\subsection{Incentives to overinvest in inventory}

The final example of the value of discretion involves inventory. With the last-in, firstout (LIFO) inventory costing method, the book expense and the tax deduction assigned to inventory that is sold during the period equals the cost of the most recent inventory purchases, as opposed to the average cost of all inventory or the cost of the first inventory purchased. During periods of rising prices, the use of LIFO accounting results in lower book profit and lower taxable income than would be the case if other costing methods were used.

LIFO has the added advantage of providing discretion for managing both book income and taxable income. The flexibility arises from the fact that the most recent inventory purchases establish the expense and deduction associated with sales of inventory during that period. Therefore, managers can directly affect both the firm's income statement and its tax return by choosing the amount of inventory that they purchase at year end. If managers fully replenish their inventory, i.e., restore inventory to its levels at the beginning of the year, then all inventory is priced at current costs. If managers do not fully replenish their inventory (i.e., inventory levels shrink), then the company will "liquidate LIFO layers." To the extent inventory shrinks, the cost of inventory for financial reporting and tax purposes is not the current costs, but rather prior costs, which will be less than current costs if prices are rising. If these layers of earlier costs are liquidated, both net income and taxable income will be greater than if the inventory had been fully replenished. If no inventory is left at year end, then the nominal costs of the first inventory ever purchased will be expensed and deducted, causing net income and taxable income to increase.

\footnotetext{
${ }^{10}$ There may, of course, be general equilibrium price effects that dampen the effects we have been discussing. For example, if the supply of these assets is not perfectly elastic, the increased demand for highrisk ventures may increase their relative price, dampening but not eliminating the enhanced attractiveness the book and tax discretion offers.
} 
Thus, LIFO provides firms with a liquidation option that can be exercised to boost accounting earnings, albeit at a cost of increased taxes. From a tax management perspective, if the firm temporarily faces low tax rates or has expiring losses or credits, it may liquidate LIFO layers to minimize total taxes over the lifetime of the firm. Whether for book or tax management purposes, to maximize the value of the option, firms need to fully replenish their inventory levels each year end. ${ }^{11}$ Consequently, firms likely hold more inventory (at least at year end) than they would, if LIFO were not permitted. ${ }^{12}$ Moreover, to the extent suppliers recognize the inelasticity of the firm's demand for inventory, as a result of the need to replenish LIFO layers, inventory costs may be higher than would otherwise be the case. In other words, LIFO provides incentives to incur a real cost (i.e., overinvest in inventory) in order to enjoy additional book and tax discretion. ${ }^{13}$

\section{Model}

\subsection{Objectives and caveats}

The discussion above highlights several things that a unifying model should address. First, it should allow for the possibility that firms value book income as well as (the present value of) after-tax cash flows. It should also allow for the possibility that at the margin firms care about book income in one period more than in another, even allowing for discounting. Second, it should recognize that book income and taxable income are not necessarily equal. They may differ because the accounting rules require one treatment of a set of circumstances but the tax system requires something different. Differences may also arise because tax or accounting rules give a firm discretion, so that differences are the result of strategic choices. Third, when book income and taxable income diverge, it may be costly to the firm because the divergence may signal manipulation. Finally, a unifying model should be able to address the consequences of required conformity between the tax system and accounting standards. In this section, we develop a model that has these features.

Before outlining the model, we might as well be explicit about what it does not address. Although in Sect. 2 we emphasized the role of information, we do not formally model the role of information in determining the demand for financial accounting. We

\footnotetext{
${ }^{11}$ Other inventory costing methods do not enable firms to manipulate end-of-period inventory purchases to manage book earnings and taxable income. For example, under the average cost method, the cost of all inventory is considered when assigning costs. Thus, end-of-period purchases have little impact on the reported cost of inventory. Under FIFO (first-in, first-out) costing, where costs are the earliest purchases, end-of-year purchases are irrelevant for both book and tax purposes.

${ }^{12}$ Note that LIFO is not permitted under International Financial Reporting Standards (IFRS). Consequently, if IFRS is adopted in the US, LIFO will no longer be available as an inventory costing method for financial accounting purposes in the US. Since the LIFO conformity rule in the Internal Revenue Code forbids using LIFO for tax purposes unless it is also used for financial reporting purposes, IFRS adoption will eliminate LIFO for tax purposes, unless the conformity requirement is repealed.

${ }^{13}$ See Dhaliwal et al. (1994), Frankel and Trezevant (1994), and Hunt et al. (1996) for empirical evidence that firms manage their year-end purchases of inventory to manipulate book and taxable income.
} 
do this to avoid having to focus on one or a small set of agency problems, and to keep the model from being overly complicated. Instead, we employ a reduced-form model that allows for the possibility that in equilibrium the decision makers (henceforth managers) employed at public companies care about book earnings, conditional on the underlying "real" profitability (cash flows) of the corporation's operations. This possibility seems uncontroversial, given the considerable evidence that managers in various settings care enough about accounting profits to expend resources to gain favorable book treatment.

This is a natural result of some information existing that is private to managers that makes it (privately, not necessarily socially) optimal for the manager's compensation to be based (at least in part) on earnings reports. When executive compensation is set so that the incentives of the manager and the shareholders are optimally aligned, then the manager's maximizing this function will also be in the shareholders' interest. In this case, the ability to move book income may allow a manager to signal private information, as discussed in Sankar and Subramanyam (2001). Even in the absence of asymmetric information between owners and managers, the ability to shift book income may be valuable because contracts and debt covenants may (optimally) be written in terms of financial variables. However, note that although an optimal compensation scheme should be designed with an eye on deterring misleading reporting by the firm's officers, it should not eliminate earnings manipulation, because doing so would excessively constrain the ability of the shareholders to incentivize the manager to take the appropriate actions that maximize profits (Crocker and Slemrod 2005). In the model we develop below, managers have some ability to shift book income across periods, but cannot appropriate funds from the corporation.

One implication of this is that the tradeoff between cash flows and book income will vary across types of corporations and within corporations across periods. For example, Barth et al. (1998) find that as a firm's financial health decreases, its accounting earnings becomes less important in the valuation of the firm while its book value (which better measures the firm's cash liquidation value) becomes more important. Conversely, accounting earnings are more useful than cash measures in assessing the rents associated with future growth opportunities and other unrecognized assets.

This reduced-form approach also has important implications when we introduce the concept of discretion in tax and accounting choices, which we define as the capacity to shift taxable income or book income across periods. As we model discretion, it must have a nonnegative value, positive if the shifting has value (i.e., when it relaxes a binding constraint), and zero otherwise. But one can imagine situations where, given the governance and incentive alignment mechanisms of a particular corporation, investors might view the acquisition of more discretion over book income to be a negative event because it fears that managers would opportunistically exercise reporting discretion to advance their private benefit at the expense of the shareholders. Chen et al. (2007) stress the difficulty of making inferences about the relationship between observed earnings management and the informativeness of accounting systems when both the accounting information and management compensation systems are endogenously chosen and therefore endogenously reflect the potential for incentive misalignment.

The reduced-form approach also does not easily generate a normative analysis of tax and accounting policy because it neither explicitly accounts for the extent to 
which managerial incentives are aligned with shareholders' incentives nor addresses the social benefits of access to information and how they might change when policy changes; instead, it is a positive analysis of the impact of tax policy on corporate behavior. The reduced-form approach is also likely to be misleading about the impact on corporate decisions of certain non-incremental policy changes. For example, if the penalty for accounting fraud or tax noncompliance was shifted from the corporation to the manager, this would affect the structure of the optimal compensation contract, which in turn would affect the objective function of the decision maker; the analysis that follows applies to policy changes that leave the objective function unchanged.

The model also assumes perfect certainty although, in reality, uncertainty abounds and firms make real and accounting decisions based on their beliefs about the future. ${ }^{14}$ Although we could recast our two-period model of certainty to allow uncertainty about future cash flows and future tax policy, we believe that this would introduce more notational complexity than is justified by the additional insights. Nevertheless, we believe it is appropriate to think about our results as pertaining to a world of probabilistic decision making.

\subsection{Objective function}

To an economist, the structure of the model - a constrained maximization problemis completely standard. Potentially enlightening are the details of the relationship between the tax and accounting rules and how they affect the incentives relevant to real decisions. To an accountant, the details are familiar. Potentially enlightening is how the accounting and tax rules affect the costs and rewards of accounting and real decisions and how the model provides a structure for comparing the parameters estimated in a variety of heretofore unconnected contexts. The notation, equations, and first-order conditions of the model are collected in Tables 1, 2, and 3.

We begin by asserting that a company makes decisions in order to maximize an objective function that includes both the present value of after-tax cash flows and the financial accounting expression of those cash flows as after-tax book earnings (income) in each of two periods, referred to as period 1 and period 2. A two-period horizon is the minimal one that allows us to address shifting across time of taxable and book income.

Expression 1 is the objective function, where $\tilde{C}^{i}$ refers to after-tax cash flows in period $i, \delta$ is the economic discount factor on cash flows, and $\tilde{Y}_{B}^{i}$ refers to after-tax book profits in period $i$. Two comments on the relationship between cash flows and book income are worth highlighting for those not familiar with accounting conventions. The first is that total undiscounted cash flows equal total undiscounted book income over the two periods combined. Furthermore, accounting choices may change

\footnotetext{
${ }^{14}$ In an uncertain world, a firm might expend resources to achieve discretion in its reporting that has expected value but ultimately provides no benefit to the firm. For example, a firm may suspect that its marginal tax rate next period will be lower than it is today, perhaps because it expects a net operating loss in the next period. As a result, it may choose one investment project over another because the former produces slack in the timing of tax income and the firm would like to shift taxable income forward. Next period earnings, however, may be unexpectedly strong, so that the marginal tax rate is unchanged. In such a case, slack was created, perhaps at a cost, but ex post, it produced no benefits for the firm.
} 
Table 1 Model notation

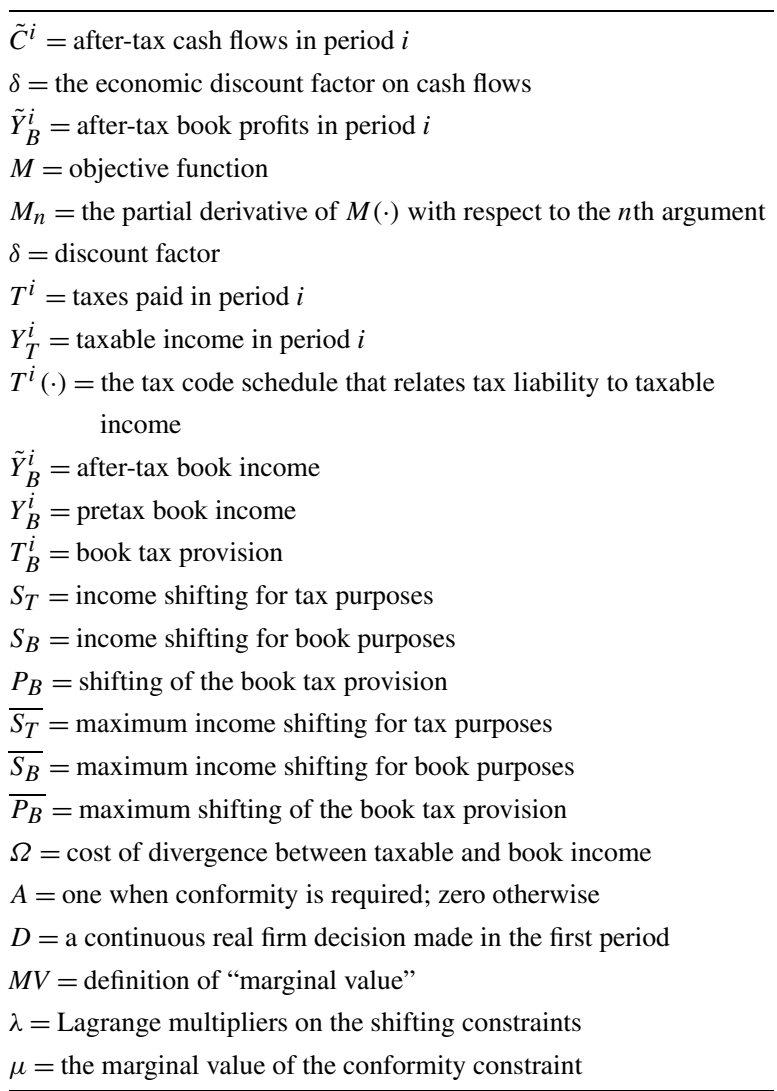

the timing of reported earnings, but it cannot change the undiscounted total amount of earnings. Second, in any single period, book income equals cash flows plus accounting accruals. Thus, over the two periods, accounting accruals must cancel out.

We assume that the function $M$ is concave and differentiable, and we use $M_{n}$ to denote the partial derivative of $M(\cdot)$ with respect to the $n$th argument of the function. We use tildes to denote after-tax outcomes to eliminate the need for an additional subscript. Superscripts denote the period, while subscripts denote variables that are defined and measured by the tax system ( $T$, for tax) or GAAP ( $B$, for book), respectively. $^{15}$

The standard economic modeling of real business decisions would include only the first argument of this function, ignoring the possibility that firms might value accounting (i.e., book) earnings. Our setup allows the firm to tradeoff book income and cash flows, and $M_{2} / M_{1}$ represents the "exchange rate," or tradeoff, between the current period's financial reporting considerations (in this case, book income) and current cash flow that many accounting studies have addressed (see Matsunaga et al. 1992; Engel et al. 1999; and Dyreng 2009, among others, discussed in Sect. 2).

\footnotetext{
${ }^{15}$ Here, and throughout, parentheses denote functions, not multiplication.
} 
Table 2 Model equations

$$
\begin{aligned}
& M\left(\tilde{C}^{1}+\delta \tilde{C}^{2}, \tilde{Y}_{B}^{1}, \delta \tilde{Y}_{B}^{2}\right) \\
& Y_{T}^{i}=Y_{T}^{i}\left(C_{1}^{1}, \ldots, C_{J}^{1} ; C_{1}^{2}, \ldots, C_{J}^{2}\right)=Y_{T}^{i}\left(C^{1}, C^{2}\right) \quad \text { for } i=1,2 \\
& T^{i}=T^{i}\left(Y_{T}^{i}\right) \quad \text { for } i=1,2 \\
& \tilde{C}^{i}=\sum_{j} C_{j}^{i}-T^{i} \quad \text { for } i=1,2 \\
& Y_{B}^{i}=Y_{B}^{i}\left(C_{1}^{1}, \ldots, C_{J}^{1} ; C_{1}^{2}, \ldots, C_{J}^{2}\right)=Y_{B}^{i}\left(C^{1}, C^{2}\right) \quad \text { for } i=1,2 \\
& T_{B}^{i}=T_{B}^{i}\left(T^{1}, T^{2}\right) \quad \text { for } i=1,2 \\
& T^{1}+T^{2}=T_{B}^{1}+T_{B}^{2} \\
& \tilde{Y}_{B}^{i}=Y_{B}^{i}-T_{B}^{i} \quad \text { for } i=1,2 \\
& \left|S_{T}\right| \leq \overline{S_{T}} \\
& \left|S_{B}\right| \leq \overline{S_{B}} \\
& \left|P_{B}\right| \leq \overline{P_{B}} \\
& \Omega=\Omega\left(S_{B}-S_{T}\right) \\
& \tilde{C}^{1}=\sum_{j} C_{j}^{1}-T^{1}\left(Y_{T}^{1}\left(C^{1}, C^{2}\right)-S_{T}-\Omega\left(S_{B}-S_{T}\right)\right)-\Omega\left(S_{B}-S_{T}\right) \\
& \tilde{C}^{2}=\sum_{j} C_{j}^{2}-T^{2}\left(Y_{T}^{2}\left(C^{1}, C^{2}\right)+S_{T}\right) \\
& \quad \tilde{Y}_{B}^{1}=\left[Y_{B}^{1}\left(C^{1}, C^{2}\right)-S_{B}-\Omega\left(S_{B}-S_{T}\right)\right]-\left[T_{B}^{1}\left(T^{1}, T^{2}\right)-\tau S_{B}-P_{B}\right] \\
& \tilde{Y}_{B}^{2}=\left[Y_{B}^{2}\left(C^{1}, C^{2}\right)+S_{B}\right]-\left[T_{B}^{2}\left(T^{1}, T^{2}\right)+\tau S_{B}+P_{B}\right] \\
& A\left[S_{B}-S_{T}\right]=0 \\
& L=M\left(\tilde{C}^{1}+\delta \tilde{C}^{2}, \tilde{Y}_{B}^{1}, \delta \tilde{Y}_{B}^{2}\right)+\lambda_{T}\left[\overline{S_{T}}-S_{T}\right]+\lambda_{B}\left[\overline{S_{B}}-S_{B}\right] \\
& \left.\quad+P_{B}\right]+\mu A\left[S_{B}-S_{T}\right] \\
& \hline
\end{aligned}
$$

The objective function also accommodates the possibility that firms value an additional dollar of (discounted) book income in one period more than in another; that is, it allows $M_{2} \neq M_{3}$. This may be the case, for example, if a manager seeks to smooth earnings, create an upward trend in earnings, maximize compensation that is determined on a period-specific basis, such as bonuses (see Healy 1985), or meet some other earnings target. We include the discount factor, $\delta$, as a multiplicative factor on the second-period book income simply as a notational matter to provide symmetry with the discounting of cash flows. It implies that if $M_{2}$ (the marginal value of first-period book income) were to equal $M_{3}$ (the marginal value of second-period income), then the company would be indifferent at the margin between first-period book income and the discounted present value of second-period book income; however, the objective function is flexible enough so that, when $M_{2}$ does not equal $M_{3}$, this need not be true. Indeed, when $M_{2}=\delta M_{3}$, the company is indifferent, at the margin, between undiscounted book earnings in the two periods. Because total undis- 
counted book income must equal total undiscounted cash flows over the life of the firm, spending cash to boost earnings in the current period must result in lower earnings in the future. Thus, it is probably best to think of, for example, the tradeoff of 0.11 (i.e., 11 cents of tax for one dollar of earnings), estimated by Erickson et al. (2004), as reflecting $\left(M_{2}-\delta M_{3}\right) / M_{1} .^{16}$

The next several equations present key identities that detail how the tax code and GAAP transform cash flows into measures of taxable income and book earnings, respectively. To accommodate the fact that neither the tax system nor GAAP treats all types of cash flows equivalently, we explicitly distinguish a vector of distinct cash flow categories $(j=1, \ldots, J)$ that may be treated differently by either the tax code, GAAP, or both. ${ }^{17}$ Equation (2) defines taxable income, which depends on the categories of cash flows in both periods. We write this function in a very general way to allow for the possibility that two streams of cash, even if they are identical in every period, may have different implications for taxable income. ${ }^{18}$ The notation $C^{i}$ represents the vector of cash flow categories in period $i$. Equation (3) defines taxes paid in a period as a function of taxable income in that period $\left(Y_{T}^{i}\right)$, where $T^{i}(\cdot)$ is the tax code schedule that relates tax liability to taxable income. For simplicity, we assume that one period's taxable income cannot affect another period's tax liability. ${ }^{19}$ Equation (4) expresses the total after-tax cash flow in a period as the sum of pre-tax cash flows over these $J$ categories minus taxes paid $\left(T^{i}\right)$.

Equation (5) defines book income. As with income for tax purposes, book income depends in a general way on the cash flows, depending on the category of cash flow. Critically, the function that maps cash flows into book income is distinct both from the $Y_{T}^{i}$ function that determines taxable income, and from the discounted cash flow.

Equation (6) introduces a key accounting concept, the "book tax provision," which is the expense for income taxes that is recorded in financial statements. It measures the past, present, and estimated future taxes triggered by economic activity in the period. Thus, (6) expresses a single period's book tax provision as a function of taxes paid to the IRS in both periods. Equation (7) notes that, over the life of the firm (two

\footnotetext{
${ }^{16}$ In Erickson et al. (2004), 0.11 is the ratio of total cash flow costs to total book income increases, while $\left(M_{2}-\delta M_{3}\right) / M_{1}$ is a ratio of marginal values.

${ }^{17}$ Examples of differences in book and tax treatment abound (see Graham et al. 2011; Raedy et al. 2010; and Hanlon and Heitzman 2010). One "permanent difference" (i.e., where total undiscounted book income does not equal total undiscounted taxable income) is tax-exempt municipal bond interest, which is income for book purposes but not for tax purposes. One "temporary difference" (i.e., where total undiscounted book income eventually equals total undiscounted taxable income) is installment sales, which are recorded as income for book purposes at the time of the sale but only considered as taxable income when the payments are received.

${ }^{18}$ The same cash flows can be taxed differently in different periods for many reasons, including if the tax law changes, the source of the income changes, e.g., internal transfer prices or repatriation of foreignsource income can make the cash flows subject to different taxing authorities, or the character of the income changes, e.g., from ordinary income to capital gains when securities are sold.

${ }^{19}$ This assumption prevents us from directly addressing the implications of such tax code features as limited tax loss refundability, loss carryforward, and carryback rules. This could be easily introduced, although at the cost of further notational complexity and with little effect on the conclusions. For example, while carryovers would mitigate the starkness of the model and reduce the returns to discretion, the implications of the model are unchanged.
} 
periods in this model), the sum of the book tax provisions must equal the sum of taxes paid. Because the sum of pretax book income equals the sum of pretax cash flows, then the sum of after-tax book income equals the sum of after-tax cash flows. Equation (8) states that after-tax book income $\left(\tilde{Y}_{B}^{i}\right)$ is the pretax book income from a period $\left(Y_{B}^{i}\right)$ minus the book tax provision $\left(T_{B}^{i}\right)$.

\subsection{Flexibility and shifting}

We next introduce the concept of flexibility. In our model, a firm has flexibility to the extent that it is able to shift pretax book income, taxable income, or the book tax provision across time. Three separate shifting possibilities arise because, by altering non-conforming accounts (those where book and tax accounting differ), firms can shift taxable income without affecting book income and vice versa. ${ }^{20}$ Furthermore, with or without conformity, they can shift the book tax provision without affecting taxable income or book income. ${ }^{21}$ The amounts shifted are introduced as choice variables, $S_{T}$ and $S_{B}$, which denote income shifting for tax and book purposes, respectively, and $P_{B}$, which denotes the shifting of the book tax provision.

Each of these choice variables is subject to a constraint, as shown in (9), (10), and (11). For any given set of real decisions made by the firm there is a limited amount of flexibility, or slack, in book income, taxable income, and the book tax provision. Given the maximum available slack, the firm chooses a level of shifting to maximize its objective function. As defined, a positive $S_{T}$ defers taxable income and, therefore, tax payments, to the second period and so moves after-tax cash flows up to the first period. Similarly, a positive value of $S_{B}$ moves book income to the second period. Every dollar of pretax book income shifted requires that $\tau$ dollars of book tax provision be booked in the second period, where $\tau$ is the statutory tax rate on corporate income. A positive value of $P_{B}$ denotes shifting of the book tax provision to the second period, and thus reduces after-tax book income in the second period.

A key aspect of our model is that we will allow each type of flexibility to be a function of the firm's real actions. If a firm undertakes a set of activities, these activities will generate some level of flexibility. Given this flexibility, the firm will choose the optimal amount of shifting. The interaction between "normal" business operations and shifting comes from the fact that firms recognize the value of flexibility and, therefore, ceteris paribus, prefer actions that create flexibility. The model makes a sharp distinction between discretionary and nondiscretionary choices. This distinction is meant to indicate that there is a class of choices that are well understood and

\footnotetext{
${ }^{20}$ For example, firms can shift taxable income by accelerating or delaying the timing of their pension contributions because pension contributions are deducted from taxable income when made. The timing of the pension contributions has no effect on book income because pension expenses for book purposes are based on estimates of the future pension payments created by an employee's work in the current period. Because pension expenses are estimated at the time that services are performed, firms can shift book income without affecting taxable income by choosing a higher or lower estimate of the current period's pension expense, which is obviously based on judgments about the employee's future compensation, including whether they will retire at that firm and rates of return on pension assets.

${ }^{21}$ For example, the options under APB 23 for recording a residual US tax on foreign-source income enable shifting of the book tax provision without affecting taxable or book income. See the discussion in Sect. 3 about this option for permanently reinvested foreign earnings.
} 
signal nothing about either tax or book aggressiveness. In practice, however, the distinction between discretionary and nondiscretionary choices is less clear to the users of financial statements, the IRS, and researchers. Although by assumption income shifting pertains to temporary, rather than permanent, differences between book and tax accounting, our formulation of the $Y_{B}$ and $Y_{T}$ functions is general enough to allow permanent differences between book and tax, so that the book "effective tax rate," defined as the ratio of the (total) book tax provision to book pretax earnings, need not equal the statutory tax rate.

The fact that the firm is constrained in its ability to shift taxable income and book income is represented by the expressions, $\overline{S_{T}}, \overline{S_{B}}$, and $\overline{P_{B}}$, which are the maximum amounts that the firm can shift under the tax code and GAAP. ${ }^{22}$ The model accommodates the idea that discretion may or may not be valuable to a firm, depending on its situation. As we elaborate below, if an action creates additional discretion, this is only valuable if that discretion is to be used. Mathematically, discretion has marginal value if and only if the shifting constraints are binding. ${ }^{23}$

We introduce one final wrinkle. As discussed above, in some circumstances the capital markets (Hanlon 2005; and Lev and Nissim 2004) and/or the IRS (e.g., Mills 1998) may believe that large book-tax differences signal potential manipulation of financial information. Thus, it may be costly for firms when discretionary shifts of taxable $\left(S_{T}\right)$ and book income $\left(S_{B}\right)$ diverge. ${ }^{24}$ To capture this notion, we define the function $\Omega$, as shown in (12), where $\Omega(0)=0$. To incorporate any costs associated with book-tax differences, we subtract the cost from first-period book income and first-period cash flow, and assume it is subtracted in the calculation of taxable income.

When we add the notion of discretion, the capacity to shift, and the cost of divergence, the equations defining after-tax cash flows and book income become (13) and (14).

\subsection{Book-tax conformity}

In recent years, the divergence between book income and taxable income has led to calls from some policy makers and scholars to force firms to report more, or all, aspects of their operations identically for book and tax purposes. ${ }^{25}$ Because, from its inception, corporate tax law has been built on the financial accounting system, in the absence of specific exceptions in the tax law transactions continue to be treated the

\footnotetext{
${ }^{22}$ Implicitly, shifting that exceeds this limit is subject to unacceptably high IRS penalties or SEC sanctions. Note that, as an alternative to introducing caps, we could have posited a "cost of shifting function" that allows the firm to shift any amount while incurring a convex cost. The cost function could also take the firm's real decision as an argument, allowing real decisions to shift the cost schedule. This is a common approach in the analysis of tax avoidance and income shifting. See Slemrod (2001) for an example in economics and Stocken and Verrecchia (2004) for an example in accounting.

${ }^{23}$ In the first-order conditions discussed later, this will be synonymous with a nonzero Lagrange multiplier.

${ }^{24}$ Note that $S_{T}$ and $S_{B}$ can only diverge if a transaction is accounted for differently for book and tax purposes. If they are accounted for the same, shifting may occur. However, $S_{T}$ and $S_{B}$ will not diverge because both $S_{T}$ and $S_{B}$ will be moving together.

${ }^{25}$ See Hanlon and Shevlin (2005) and Hanlon and Maydew (2008) for a detailed analysis of the benefits and costs associated with book-tax conformity.
} 
same for book and tax. However, over time, Congress has passed many provisions that specify a different treatment for tax than for GAAP. These tax-only provisions increase divergence between book accounting and tax accounting.

Proponents of increased book-tax conformity (legislated, rather than the default form of conformity that now exists) argue that permitting or requiring firms to account for transactions one way for their shareholders and another way for the IRS produces misleading reports for both audiences, e.g., overstated accounting earnings and understated taxable income. In the context of our model, they are arguing that managers have too much discretion, and that conformity would rein in some of that discretion. Those who oppose conformity argue that it is appropriate that the two audiences receive different information because the purposes and uses of financial reports and tax returns differ.

While this paper takes no position on legislated book-tax conformity, it is relevant here because it would increase the number of situations in which firms would have to trade off book and tax incentives. The tradeoff literature suggests that, in some situations, firms would take positions to enhance their book earnings (and thus arguably provide misleading tax reports) and at other times, they would take positions to reduce their tax liabilities (and thus arguably produce misleading financial reports) (see Shackelford and Shevlin 2001 for examples). Either way, more book-tax conformity would increase the need for managers to coordinate their book and tax choices while reducing the current financial accounting and tax costs associated with book-tax divergence.

Our model can address any form of book-tax conformity. As discussed above, many transactions are treated the same for book and tax purposes. If GAAP and tax treatment were always the same, i.e., complete book-tax conformity, then taxable income would equal pretax book income and, in terms of our notation, $Y_{B}$ would equal $Y_{T}$ in both periods. However, not all transactions are treated differently for book and tax. Thus, current practice is characterized by "partial conformity." Our notation easily accommodates the notion of partial conformity by requiring some subset of the cash flow categories to have identical effects on taxable income and book income.

We introduce an additional element of conformity to our analysis of discretion by allowing that there may be a constraint requiring $S_{T}$ to equal $S_{B} \cdot{ }^{26}$ Equation (15) represents the conformity constraint. The term $A$ is a zero-one dummy variable indicating whether or not tax and book transfers must conform. ${ }^{27}$ If the government requires conformity, then $A=1$, and any shifting of book income must match the shifting of tax income. If the government does not require conformity, then $A=0$, and the tax shifting may differ from the book shifting. Conformity generates interaction by linking the values of book and tax discretion. For example, additional discretion in book income might be valuable even if a firm is indifferent to the timing of book earnings, because it allows the shifting of taxable income across periods.

\footnotetext{
${ }^{26}$ Note that imposing this constraint is equivalent to specifying that $\Omega$ goes to infinity whenever $S_{T}$ and $S_{B}$ diverge.

${ }^{27}$ Technically, the $A$ variable concerns what one might call "marginal conformity," i.e., whether shifts from baseline "unmanipulable" measures of book and tax income must be equal. This is a different concept than "partial conformity," which refers to the fact that some aspects of accounting are the same for tax and book purposes, and some are not.
} 
Table 3 First-order conditions of the model

$$
\begin{aligned}
& \sum_{j} \frac{\partial C_{j}^{1}}{\partial D}+\delta \sum_{j} \frac{\partial C_{j}^{2}}{\partial D}-\sum_{i} \sum_{j}\left[T^{1}{ }^{\prime} \frac{\partial Y_{T}^{1}}{\partial C_{j}^{i}}+\delta T^{2}{ }^{\prime} \frac{\partial Y_{T}^{2}}{\partial C_{j}^{i}}\right] \frac{\partial C_{j}^{i}}{\partial D}=0 \\
& M V C_{j}^{1} \equiv M_{1}+M_{2} \frac{\partial Y_{B}^{1}}{\partial C_{j}^{1}}+\delta M_{3} \frac{\partial Y_{B}^{2}}{\partial C_{j}^{1}} \\
& M V C_{j}^{2} \equiv \delta M_{1}+M_{2} \frac{\partial Y_{B}^{1}}{\partial C_{j}^{2}}+\delta M_{3} \frac{\partial Y_{B}^{2}}{\partial C_{j}^{2}} \\
& M V T^{1} \equiv M_{1}+M_{2} \frac{\partial T_{B}^{1}}{\partial T^{1}}+\delta M_{3} \frac{\partial T_{B}^{2}}{\partial T^{1}} \\
& M V T^{2} \equiv \delta M_{1}+M_{2} \frac{\partial T_{B}^{1}}{\partial T^{2}}+\delta M_{3} \frac{\partial T_{B}^{2}}{\partial T^{2}} \\
& \frac{\partial L}{\partial D}=\sum_{j}\left[M V C_{j}^{1}\right] \frac{\partial C_{j}^{1}}{\partial D}+\sum_{j}\left[M V C_{j}^{2}\right] \frac{\partial C_{j}^{2}}{\partial D} \\
& -\sum_{i} \sum_{j}\left[M V T^{1}\right] T^{1 \prime} \frac{\partial Y_{T}^{1}}{\partial C_{j}^{i}} \frac{\partial C_{j}^{i}}{\partial D}-\sum_{i} \sum_{j}\left[M V T^{2}\right] T^{2 \prime} \frac{\partial Y_{T}^{2}}{\partial C_{j}^{i}} \frac{\partial C_{j}^{i}}{\partial D}=0 \\
& \frac{\partial L}{\partial D}=\sum_{j}\left[M V C_{j}^{1}\right] \frac{\partial C_{j}^{1}}{\partial D}+\sum_{j}\left[M V C_{j}^{2}\right] \frac{\partial C_{j}^{2}}{\partial D} \\
& -\sum_{i} \sum_{j}\left[M V T^{1}\right] T^{1} \frac{\partial Y_{T}^{1}}{\partial C_{j}^{i}} \frac{\partial C_{j}^{i}}{\partial D}-\sum_{i} \sum_{j}\left[M V T^{2}\right] T^{2 \prime} \frac{\partial Y_{T}^{2}}{\partial C_{j}^{i}} \frac{\partial C_{j}^{i}}{\partial D} \\
& +\lambda_{T} \overline{S_{T}^{\prime}}+\lambda_{B} \overline{S_{B}^{\prime}}+\lambda_{P} \overline{P_{B}^{\prime}}=0 \\
& \frac{\partial L}{\partial S_{T}}=\left[M V T^{1}\right] T^{1 \prime}-\left[M V T^{2}\right] T^{2 \prime}+\left[M_{1}+M_{2}-\left[M V T^{1}\right] T^{1 \prime}\right] \Omega^{\prime}-\lambda_{T}-\mu A=0 \\
& \frac{\partial L}{\partial S_{B}}=-M_{2}[1-\tau]+\delta M_{3}[1-\tau]-\left[M_{1}+M_{2}-\left[M V T^{1}\right] T^{1 \prime}\right] \Omega^{\prime}-\lambda_{B}+\mu A=0 \\
& \frac{\partial L}{\partial P_{B}}=M_{2}-\delta M_{3}-\lambda_{P}=0
\end{aligned}
$$

\section{Optimal real decisions}

To analyze the interaction between real and accounting considerations, we next introduce a continuous real decision, $D$, made by the firm in the first period. This decision could be the purchase of a capital good, a decision to undertake research and development, where to locate a plant, how to finance capital, or any number of decisions that a firm must make. This decision affects the firm's cash flows and the discretion available to the firm. In the remainder of this section, we demonstrate how accounting considerations influence the optimal choice of $D$, given that $D$ may affect the amount of discretion available to the firm. The firm's optimization problem can be rewritten by substituting (13) and (14) into (1), taking (9) through (12) as constraints. 
Equation (16) shows the Lagrangean, labeled $L$. The firm makes it real decision $D$, and also chooses $S_{T}, S_{B}$ and $P_{B}$. The terms $C_{j}, \overline{S_{T}}, \overline{S_{B}}$ and $\overline{P_{B}}$ are all a function of the real decision $D$.

\subsection{Optimal real decisions without accounting considerations- the standard economics approach}

In the interest of building intuition, rather than immediately analyzing the general case, we begin by describing the optimal choice of $D$ when there are no financial accounting considerations and no shifting choices. In this case, $D$ determines cash flows and, in turn, determines tax obligations. This is, of course, the standard economics approach that ignores accounting.

To characterize the effects of taxes on real and accounting decisions, we derive the first-order conditions that characterize an optimal choice. We presume that the optimal decision is an interior solution (i.e., it is nonzero), and so the firm should pursue this activity until its marginal contribution to firm value, $M$, is zero. ${ }^{28}$

If neither book income, discretion, nor conformity is of concern, then the firstorder condition simplifies to something familiar: $D$ should be set so that at the margin the present value of after-tax cash flows equals zero. This is shown in expression (F1). For functions with a single argument, a prime indicates the first derivative of that function with respect to its argument, so that $T^{i \prime}$ is the marginal tax rate in period $i$, defined as the change in tax liability due to a marginal change in taxable income. The first two summations are just the marginal change in the pretax cash flows, summed over all categories of cash flow, in each period. The value of these cash flows is eroded by the additional tax obligations that they trigger, i.e., the marginal increase in total discounted present value of tax liabilities. A marginal increase in cash flow $\left(\frac{\partial C_{j}^{1}}{\partial D}\right)$ may trigger a change in taxable income $\left(\frac{\partial Y_{T}^{1}}{\partial C_{j}^{1}}\right)$ in both periods. Each change in taxable income is multiplied by the marginal tax rate $\left(T^{1 \prime}\right)$ to determine the change in tax obligation. Note that because the model is based on a set of cash flow categories, this framework allows that the tax obligations triggered by two actions that generate the same total pretax cash flow in each period need not be the same.

\subsection{Optimal real decisions when book income matters}

When managers care about book income as well as real cash flows, the marginal value of any decision depends not only on how it affects after-tax cash flows, but also on how it affects book income in both periods. It becomes possible that a corporation will want to undertake a marginal real activity even if it reduces the present value of after-tax cash flows.

To capture this value in a parsimonious way, we introduce in expressions (F2) the concept of a marginal value $(M V)$, where each $M V$ term takes into account the

\footnotetext{
${ }^{28}$ If $D$ were a lumpy, rather than a continuous, decision, the first-order (equality) conditions that follow can be thought of as inequalities that dictate the optimal yes-or-no decision: if and only if the left-hand side (the decision's contribution to $M$ ) exceeds zero should the firm "do" $D$.
} 
marginal value to the firm of both the cash flows and book income in each period, through the $M_{n}$ terms. Recall that $M_{1}, M_{2}$ and $M_{3}$ are the derivatives of the objective function $M(\cdot)$ with respect to each of its three arguments (the present-value of real after-tax cash flows, period 1 after-tax book income, and (discounted) period 2 aftertax book income). ${ }^{29}$ For example, the $M V$ of an increase in cash flow from category $j$ in period 1 is the value of the cash flow $\left(M_{1}\right)$, plus the marginal increase in period 1 book income multiplied by the marginal value of period 1 book income $\left(M_{2}\right)$, plus the analogous (discounted) term for period 2 book income.

When the firm is concerned with book income as well as real cash flows, the firstorder condition for the optimal $D$ will reflect that a marginal change in $D$ adds (or subtracts) value through its effect on after-tax book income. Using the $M V$ notation, we can write the first-order condition in this more general case as in (F3). This optimality condition generalizes the standard case because it recognizes that changes in book income affect the firm's objective to the extent that book income has marginal value in each period. If, for example, book income has a higher value in period 1 than in period 2, then $M_{2}$ exceeds $\delta M_{3}$ and the effect of $D$ on the timing of book income affects the attractiveness of $D$.

As in the standard case, the value of additional cash is eroded by the tax system. Tax obligations are increased by the marginal tax rate multiplied by the marginal increase in taxable income triggered by the rise in cash, $T^{1} \frac{\partial Y_{T}^{1}}{\partial C_{j}^{i}} \frac{\partial C_{j}^{i}}{\partial D}$. The marginal cost to the firm of an increase in tax obligations is the $M V$ of taxes in that period, which includes both the marginal value of real discounted cash flow $\left(M_{1}\right)$ and the marginal value of book income multiplied by the reduction in book income resulting from the change in the tax liability in each period $\left(M_{2} \frac{\partial T_{B}^{1}}{\partial T^{1}}\right.$ and $\left.\delta M_{3} \frac{\partial T_{B}^{1}}{\partial T^{1}}\right)$.

The expanded optimality condition highlights the mechanics of the tax system. As in the standard case, a choice $D$ that generates cash flow is less valuable if it also triggers a required payment to the IRS. The expanded optimality condition demonstrates that the total cost to the firm of paying the IRS is not just the amount of the check. The increased payment to the IRS must be accounted for in the firm's financial statements. This implies that book income will be lowered, and the value of this to the firm will depend on when the tax must be booked and the marginal value of book income in that period.

\subsection{Discretion and shifting}

Unlike in the standard economics model, the choice of $D$ may affect the constraints $\overline{S_{T}}, \overline{S_{B}}$, and $\overline{P_{B}}$, which determine how much shifting the firm is able to accomplish. By assumption, shifting incurs no cost up to the constraint, and is impossible beyond the constraint. If a firm wants to shift more than the constraint, it must undertake other activities $(D)$ that produce additional slack. As a result, real decisions may add value (i.e., increase $M$ ) by expanding the scope of discretion. ${ }^{30}$ Thus,

\footnotetext{
${ }^{29}$ Note that $M_{1}, M_{2}$ and $M_{3}$ are functions, not scalars. The marginal value of each of the three arguments of the $M(\cdot)$ function may depend on the level of the other arguments.

${ }^{30}$ Recall that our reduced-form version of the manager's objective function rules out the possibility that expanding discretion may itself affect the objective function of managers by, for example, reducing the
} 
the model highlights the link between real activities and tax and book manipulation because, to the extent that shifting has value, it may affect the real decision $D$.

The assumption that shifting is free up to a point, given the actions $D$, and impossible beyond that is consistent with a firm choice that creates a tax obligation that must be met at some point, and firms may move that obligation backward or forward, but they can do this only up to some amount. If a firm values discretion at the margin, then the optimal amount of a decision $D$ that raises discretion will be higher than it would be absent concerns about timing and discretion. Equivalently, we can say that the cost of capital for capital goods that produce (valuable) discretion is lower than it is for capital goods with the same cash-flow implications that do not create discretion. Formally, the first-order condition for $D$ becomes expression (F4).

If a real decision affects discretion by relaxing the constraints on shifting, then $\overline{S_{T}^{\prime}}$, $\overline{S_{B}^{\prime}}$, and $\overline{P_{B}^{\prime}}$ will be nonzero and will affect the real decision as long as the associated $\lambda$ value is nonzero. Formally, the $\lambda$ terms are the Lagrange multipliers on the shifting constraints in the constrained maximization problem the company solves. Informally, $\lambda_{T}, \lambda_{B}$, and $\lambda_{P}$ are equal to how much more $M$ could be achieved if the taxable income, book income, and book tax provision shifting constraints, respectively, were to be relaxed by one dollar. Henceforth, we will refer to the $\lambda$ terms as the "value" of relaxing the shifting constraints.

If a shifting constraint is not binding, so that the firm is not shifting all that it could, then the relevant $\lambda$ term is zero: the constraint imposes no cost on the firm, and thus relaxing the constraint has no value. When it is binding, $\lambda$ is positive and equal to the value of moving income between periods. Thus, for example, the term $\lambda_{B} \overline{S_{B}^{\prime}}$ is zero when the constraint on the shifting of income for book purposes is not binding, but when it is binding, it is equal to the value of relaxing the constraint by one dollar, which is equivalent to the value of moving book income between periods, multiplied by how much the real decision relaxes the constraint. In the next section, we expand on what determines the values of the $\lambda$ terms when we focus on the shifting and conformity constraints as well as the cost of divergence.

\subsection{Conformity}

It is worth noting that the first-order condition for optimal $D$ contains no term that directly relates to a conformity requirement because $D$ does not relax (or tighten) the conformity requirement the way we allow it to relax or tighten the shifting constraints. This does not, however, imply that conformity has no effect on real decisions; indeed, the opposite is true. Imposing conformity can change the real decision calculus by changing the value of discretion, which is captured by the $\lambda_{T}, \lambda_{B}$, and $\lambda_{P}$ terms.

Consider, as an example, a real decision that relaxes the constraint on book income shifting. If the constraint is otherwise binding, this makes the real decision more attractive than otherwise. Now impose conformity, and assume that the optimal response to conformity is for the firm to reduce how much taxable income it shifts

relative value of book income versus cash flows because the market becomes more suspicious of the information content of earnings figures. Fischer and Verrecchia (2000) and Stocken and Verrecchia (2004) address similar issues. 
to the second period and reduce how much book income it shifts to the first period. Moreover, suppose that the fall in book income shifting implies that the book income shifting constraint is no longer binding. Under conformity, the fact that the real decision relaxes the book income shifting constraint has no value $\left(\lambda_{B}\right.$ falls from a positive number to zero), and the real decision is less attractive than it was in the absence of conformity.

\section{Optimal shifting with real consequences}

Not only do accounting considerations affect real decisions, but real decisions also affect shifting decisions. Indeed, in our model the two sets of decisions are simultaneously determined. The firm chooses not only $D$, but also $S_{T}, S_{B}$ and $P_{B}$. We now examine the shifting decisions.

\subsection{Taxable income shifting}

Consider first the shifting of taxable income. Equation (F5) is the first-order condition that characterizes optimal taxable income shifting $S_{T}$, where $\lambda_{T}$ is the marginal value of the taxable income shifting constraint. Equation (F5) introduces a new term, denoted $\mu$, which is equal to the marginal value of the conformity constraint: how much greater $M$ could be if taxable income and book income shifting could diverge by one dollar. ${ }^{31}$

It is helpful to consider some special cases. First, assume that there are no divergence costs $\left(\Omega^{\prime}=0\right), \lambda_{T}$ is zero, and conformity is not relevant $(\mu A=0)$. In this case, the first-order condition becomes $\left[M V T^{1}\right] T^{1 \prime}=\left[M V T^{2}\right] T^{2 \prime}$, which implies that the (cash flow and book income) implications of reporting an additional dollar of taxable income in each period must be equal; if they are not, then taxable income should be shifted. This equality may not hold because a firm faces a different marginal tax rate in the two periods $\left(T^{1 \prime} \neq T^{2 \prime}\right) .{ }^{32}$ However, note that taxable income shifting can be valuable even if the marginal tax rates are equal in both periods, if the (cash flow and book income) value of a dollar of tax payments is not equal in the two periods $\left(\left[M V T^{1}\right] \neq\left[M V T^{2}\right]\right)$.

Next, consider the case in which shifting is limited, so that $\lambda_{T}$ is not zero. Then $\left[M V T^{1}\right] T^{1 \prime}-\left[M V T^{2}\right] T^{2 \prime}=\lambda_{T}$, which means that the (book-income-adjusted) tax

\footnotetext{
${ }^{31}$ Formally, $\mu$ is the Lagrange multiplier on the conformity condition.

${ }^{32}$ Although not explicitly in this model, in reality this could occur because of the limited refundability of net operating losses. The present value of the additional tax liability caused by an additional dollar of taxable income is the concept that Graham and Mills (2008) and others have tried to measure quantitatively using data from financial statements and corporate tax returns, usually referred to as the marginal tax rate. This is quite different than what tax economists call the marginal effective tax rate on an incremental dollar of investment, which is the accrual-equivalent tax rate triggered on the returns to a marginal investment, which depends not only on the statutory tax rate but also the pattern of depreciation allowances. Fullerton (1984) provides a helpful discussion of this concept. Although economists often ignore this in their calculations (although see, e.g., Auerbach 1986), in principle the marginal effective tax rate should depend on the details of limited loss refundability that are central to the marginal tax rate calculations done by accounting and finance scholars (e.g., Scholes and Wolfson 1992; and Graham 1996).
} 
arbitrage is incomplete. Because of the constraint on shifting, there may be a gain from having taxable income in one period that the firm cannot take advantage of. This reminds us that $\lambda_{T}$ is the value of being able to shift an additional dollar of taxable income between periods (or, equivalently, of the marginal cost of not being able to shift).

Finally, the relationship between the optimal $S_{B}$ and the firm's choice of $S_{T}$ is implicit in this optimality condition. The two types of shifting interact through the $\mu$ and $\Omega$ terms. When $A=1$ (conformity is required), $\mu$ will be nonzero, but $\Omega$ will be zero, because the book income shifted equals the taxable income shifted.

When $\Omega^{\prime} \neq 0$, then the effect of taxable income shifting on the cost of divergence matters. A marginal increase in $S_{T}$ may cause $\Omega$ to rise or fall, depending on whether or not $S_{T}$ is smaller than or larger than $S_{B}$, before the increase in $S_{T}$. An increase in the cost of divergence lowers total cash flow and period-one book income. It also lowers taxes paid because this cost is, by assumption, tax deductible. ${ }^{33}$

In either case, whether $\Omega^{\prime} \neq 0$ or $\mu A \neq 0$, the optimal $S_{T}$ will be linked to the firm's choice of $S_{B}$. The tension created will prevent the (book-income-adjusted) tax arbitrage from being executed fully. For example, suppose that the firm would like to move a large amount of book income to the first period, but would like to defer taxable income to the second period. In such a case, the firm may choose to set $S_{T}$ lower than is optimal from the point of view of reducing total discounted taxes paid, because doing so allows the movement of more book income to the first period. This is one example of how tax minimization is not generally an optimal strategy.

\subsection{Book income shifting}

The first-order condition with respect to book income shifting $S_{B}$ is shown in expression (F6). Firms may wish to move book income because they value discounted book income in one period more than in another, in which case $M_{2}-\delta M_{3} \neq 0$. If $\Omega^{\prime}=\lambda_{B}=\mu=0$, then book income is shifted until the marginal value of discounted after-tax book income is equal across periods. If $M_{2}=M_{3}$, the only motivation for shifting book income is that firms would prefer to report earnings sooner, due to discounting. Note also that moving one dollar of book income across periods moves only $1-\tau$ dollars of after-tax book income.

If the constraint on book shifting is binding, then $\lambda_{B}$ is positive and the marginal contribution to $M$ of shifting through its effect on book incomes, $-\left(M_{2}-\delta M_{3}\right) \times$ $(1-\tau)$, will be greater than zero by $\lambda_{B}$; the constraint limits the amount that the firm wants to shift.

There are several similarities between the optimality conditions for $S_{B}$ and $S_{T}$. The terms related to $\mu$ and $\Omega$ are exactly the same, with a change in sign, between the equations. This is because, at any given point, an increase in $S_{B}$ must have exactly the opposite effect of an increase in $S_{T}$ on the cost of divergence.

Note also that, when $\mu \neq 0$, and marginal conformity is imposed, either $\lambda_{T}$ or $\lambda_{B}$ must be equal to zero. This is because, when the two shifted amounts are forced to be

\footnotetext{
${ }^{33}$ Almost all divergence costs are deductible, e.g., legal fees and increased borrowing costs. One divergence cost that is not deductible is additional US taxes that could arise from an IRS audit.
} 
the same, only one of them can be binding. Thus, of the three values, $\lambda_{T}, \lambda_{B}$, and $\mu$, one of them is always zero.

There are two reasons that the choice of $S_{T}$ and $S_{B}$ are not independent: conformity and the cost of divergence. If conformity is an issue $(A=1)$, then shifting of taxable (book) income may become more or less attractive, depending on whether it aids or hinders book (taxable) income. Whenever $S_{T}$ and $S_{B}$ would not be equal in the absence of conformity, the conformity condition binds, and the value of $\mu$ is nonzero. When neither shifting constraint is binding, conformity means that at least one type of shifting will have to change; if both change, they will change in opposite directions. This is reflected by the fact that the $\mu A$ terms enter the first-order condition for $S_{T}$ and $S_{B}$ with opposite sign. If conformity puts upward pressure on $S_{T}$, then adding the $\mu A$ term means that the marginal contribution to the discounted value of cash flow will just equal minus one times the value of the conformity constraint, so that the marginal tax saving is actually negative.

Conversely, if conformity puts downward pressure on book income shifting, the marginal contribution to the value of book income will be equal to the (positive) value of the conformity constraint, so that at the margin there would be additional value from booking income, if not for the conformity constraint. If both the shifting and conformity constraints are binding, (so that absent any constraints $S_{T}$ and $S_{B}$ would be different and at least one would exceed the shifting limit), both the $\mu$ and (at least one) $\lambda$ terms are relevant.

If divergence between tax and book income is costly $\left(\Omega^{\prime} \neq 0\right)$, then optimal shifting of both tax and book must account for the fact that shifting book or tax items without shifting the other item will affect the amount of book-tax differences and change the cost of such divergence. Note that the two bracketed terms that involve $\Omega$ appear in an equal, but differently signed, way in the two first-order conditions. That reflects the fact that if increasing $S_{T}$ has a marginal divergence cost, then decreasing $S_{B}$ must have the same marginal cost.

\subsection{Shifting the book-tax provision}

The firm's optimization problem involves one final choice, the shifting of the book tax provision, $P_{B}$. The first-order condition for this choice, shown in expression (F7), is very simple. It represents the fact that, when a firm increases $P_{B}$ (i.e., moves a dollar of book-tax provision to the second period), it directly transfers one dollar of after-tax, book income from the second period to the first period. The firm will shift the provision in this manner until after-tax book income is equally valuable across periods, unless it is constrained in the amount of available discretion.

Note that this choice will interact with the other shifting decisions. If a firm has considerable discretion in timing the book tax provision, it may use this discretion to equalize the value of after-tax book income over time. This lowers the value of shifting pretax book income.

When conformity between $S_{T}$ and $S_{B}$ is binding (or divergence is very costly), shifting of the book tax provision may enable the firm to circumvent the conformity constraint. Consider a firm that would like to move taxable income into the second period, but places a high marginal value on after-tax book income in the current 
period. Under conformity, the firm cannot use its discretion to do both. If this firm has considerable discretion in the timing of its book tax provision, however, it could move taxable income into the second period, along with a matching amount of book income, and then offset the loss of pretax book income in the first period by reducing $P_{B}$ in the first period.

Note that the substitutability of shifting book income and changing the timing of the book tax provision assumes that the benefits to managing after-tax earnings, using the book tax provision, are the same as shifting (an after-tax equivalent amount of) pretax earnings. The findings in Robinson (2010) challenge this assumption. In her study of investments in housing tax credits, she finds that firms value pretax book earnings more than reductions in the book tax provision. If her findings generalize, then firms may have to shift larger amounts of book tax provision to reduce financial reporting costs the same as with a smaller portion of book income shifting. Her findings are consistent with analysts and others using operating earnings, earnings before tax, depreciation, and amortization (EBITDA), or similar measures that ignore the book tax provision to value a firm.

\subsection{Summary of results}

The formal analysis of this model suggests that the attractiveness of a real decision depends on both its effect on discounted after-tax cash flow and its effect on book income. A key result is that the attractiveness of a real decision depends on whether it expands the discretion of both book and tax accounting. If the real decisions of the firm affect the discretion the firm has in timing its taxable income, pretax book income, and book-tax provision, then tax payments and book income may be moved to periods when it is of maximum value to the firm. Discretion has value because if certain business operations induce a firm to show particularly high or low book income in a period, the firm may want to smooth its earnings through discretionary book accruals. Likewise, if normal business operations lead to different marginal tax rates, perhaps through net operating losses, then an ability to shift taxable income will become important. However, real decisions that provide discretion lose value if the real decision leads to a costly divergence between pretax book income and taxable income.

\section{Implications for research and policy}

The effect of tax changes that are equivalent in the standard economic model may not be the same when accounting considerations enter. We have argued that ignoring these book considerations can lead economists to be surprised at the corporate behavioral response to tax policy and at the policies that business interests favor.

\subsection{Econometrics}

The framework we propose suggests that standard empirical research designs may lead to biased estimates of the effect of tax system changes to the extent they ignore 
the relevant accounting issues. For example, the true, accounting-adjusted effective tax rate for some choices differs depending on the value to a firm of the accounting discretion that the choice offers. This will vary depending on the firm and, more importantly, aspects of the firm's current and future real and accounting situations. One natural research design is to interact the standard measure of marginal effective tax rates with indicators of the value of the marginal accounting discretion the decision provides. ${ }^{34}$ This will allow for the estimation of heterogeneous behavioral responses across firm types and circumstances.

\subsection{Policy: The Neubig conjecture and conformity}

As an example of the policy implications of this unifying model, consider two alternative tax policies that are designed to make investment more attractive-a decline in the corporate tax rate versus immediate expensing for tax purposes. It is clear that both a reduction in marginal tax rates and a postponement of tax payments increase the attractiveness of a real investment decision, and that there is some level of rate reduction that would have the same effect on the incentive to invest as immediate expensing (i.e., postponement of tax payments).

Neubig (2006) shows that, once financial accounting implications are considered, the lower corporate tax rate generally dominates expensing. The reason is that, even if the present values of the after-tax cash flows from the investment are identical with a rate reduction, the lower tax rate accelerates book profits. In terms of our model, the values of $\tilde{Y}_{B}^{1}$ and $\tilde{Y}_{B}^{2}$ matter, in addition to the present value of the after-tax cash flows. That is, the present value of book earnings is greater with a lower tax rate than with expensing. This occurs because expensing does not change the book tax provision, i.e., the reduction in book profits for past, present, and future taxes. Although the present value of tax payments may decline, the book tax provision remains constant because GAAP does not discount income taxes. ${ }^{35}$ On the other hand, a lower statutory corporate tax rate immediately reduces the tax rate applied to current book profits, lowering the book tax provision. Furthermore, it lowers the tax that is expected to be levied on future tax liabilities. Thus, if the firm has more deferred (or future) tax liabilities than deferred tax assets, as is the case for most firms, then there is a further boost to earnings because the deferred tax liabilities are revalued using the new corporate tax rate and the change is included as accounting income. ${ }^{36}$ Of course, for those companies where the deferred tax assets exceed the deferred tax liabilities,

\footnotetext{
${ }^{34}$ See our discussion in footnote 32 about the different concepts of tax rates used in the accounting and economics literature.

${ }^{35}$ The absence of discounting for financial accounting purposes is not unique to the income tax accounts. Many accounts involving future receipts or payments, e.g., accounts receivable and accounts payable, are not discounted. Although discounting likely would result in deferred tax assets and liabilities on the balance sheet that better approximate current market values, the process of selecting a discount rate and estimating the timing of future tax payments and refunds would add considerable complexity and judgment to an area of financial accounting that already is arguably the most complex and among those requiring the greatest amount of judgment. Furthermore, a need for more judgment would enhance opportunities to manipulate earnings through the tax accounts.

${ }^{36}$ This accounting issue is reminiscent of the distinction in economic analysis between the effects of a tax change on "old capital" versus "new capital." Other things equal, the bang (i.e., increased incentive to
} 
the firm's book income falls with a rate reduction and thus they would be more likely to oppose a lower tax rate.

For example, suppose a firm has no deferred tax assets and \$100 in deferred tax liabilities (arising from installment sales that have been recorded for book purposes but not yet taxed because the payments have not been received). If the tax rate is halved, the deferred tax liabilities will be reduced to $\$ 50$ and the offsetting journal entry will increase current book profits by $\$ 50$. The logic for the boost to profits is that when the installments are received and taxed, they will be subject to a lower tax rate than anticipated when the sale was booked. Conversely, suppose the firm has no deferred tax liabilities and \$100 in deferred tax assets (arising from net operating loss carryforwards). If the tax rate is halved, the deferred tax assets will be reduced to $\$ 50$ and the offsetting journal entry will decrease current book profits by $\$ 50$. The logic for the charge to earnings is that when the net operating loss carryforwards are offset against future income, they will not reduce taxes (because tax rates have declined) as much as anticipated when the losses were recorded for book purposes. Thus, the impact on current book profits of a change in the tax rate depends on whether the firm has more deferred tax liabilities or assets at the time of the change in the tax law. ${ }^{37}$

Another current policy debate concerns conformity, i.e., the requirement that book and taxable income be the same. Firms currently report taxable income to the IRS according to tax law, and report book income to the public according to GAAP. The support for conformity is partly a response to the fact that these two sets of reports have been diverging in recent years, leading many analysts to conclude that firms are systematically inflating earnings and avoiding taxes. Advocates of conformity suggest that folding both systems into one would reduce the incentive to manage earnings (since taxes would be owed on any fictitious earnings), reduce tax avoidance, as well as reduce compliance costs because it eliminates the need to make two separate calculations of income. Opponents point out that book income, despite its many problems, is a strong signal of firm value to the investing public, and they are concerned that reforms might lower the quality of that signal. ${ }^{38}$

The model developed here adds a new perspective to this debate. Not only would conformity affect the book reporting of income and the taxable income reported to the IRS for any set of underlying real operations, it would also affect these real decisions themselves. Firms will be less likely to engage in real activities that give them more

invest) per buck (i.e., revenue lost) of an investment tax credit or accelerated depreciation exceeds that of a tax rate cut because the latter provides tax relief for income generated by past investments, which is wasted in terms of providing an incentive to future investment. The effect on the value of deferred tax assets or liabilities reflects the impact on the value of the corporation of the tax implications of past investments, or "old capital."

${ }^{37}$ Hodder et al. (2003) find that the presence of deferred tax assets kept some privately held banks from escaping corporate taxes completely. Examining banks following a 1996 change in the tax law that permitted them to convert from taxable $C$ corporation status to pass-through $S$ corporation status (which effectively imposes a zero corporate tax rate), they report that conversions were less likely for those banks with significant deferred tax assets. The reason was that, even though conversion would lead to lower taxes in the future, the write-off of the deferred tax assets (because they would be useless under $S$ corporate treatment) would result in an immediate charge to earnings, and thus reduce their regulatory capital.

${ }^{38}$ There are several versions of conformity that might be implemented, and we do not attempt to distinguish between them here. See Hanlon et al. (2005) and Hanlon and Maydew (2008) for overviews. 
discretion to report current book income if it also necessarily increases current tax payments. Whether that is a good thing or a bad thing depends on whether or not the book income and discretion advantages of an asset move the firm's choice of $D$ away from or towards the social optimum. For example, a firm may be deciding the optimal level of investment in a foreign asset. In the absence of taxes and financial accounting concerns, the firm would choose $D^{*}$. Before considering book income or shifting, but given the lower rate of return induced by taxation, firms would choose $D^{\prime}<D^{*}$. Next, suppose that higher levels of $D$ boost book income or increase discretion in periods when that is especially valuable. It is quite possible that the new optimum, call it $D^{* *}$, is closer to the social optimum, $D^{\prime}<D^{* *}<D^{*}$. ${ }^{39}$ In such a case, book and discretion considerations may partially offset the distortions of the tax code, implying that financial accounting considerations move the firm towards the social optimum.

Whether or not conformity is welfare improving will depend on whether or not book considerations exacerbate or offset the distortions induced by the tax code. Our framework is only a first step in adequately addressing this question, in part because in our reduced form approach, it is impossible to make comprehensive welfare statements. If firms value book income because they are able to fool the market, then the investing public may gain from conformity, even if it pushes firms away from optimal actions in a partial equilibrium model. If book income is valued because it is a superior signal of firm value, then the information content of the economy may be damaged by conformity. Likewise, adequate analysis of the opportunity cost of investment decisions requires general equilibrium analysis. Nevertheless, we think that our framework provides fresh insight, and we hope that it will serve as a starting point for future normative analysis of policy.

\section{Conclusions}

As long as book income has value to public corporations, real decisions that facilitate book earnings management are more attractive than otherwise, and especially so to companies for which this discretion has relatively high value. Decisions that enhance the discretion of tax payments may also be more attractive than otherwise, especially to companies that face time-varying marginal tax rates. The source of this discretion may be either the accounting rules or the tax law. It is critical to know whether the book and tax accounting either must be conformed by law, or will be conformed by choice because of the private costs of maintaining separate accounting systems. When they are not conformed, divergence between the two may be costly to the extent that it alerts the IRS to possibly aggressive tax planning or the capital markets to poor earnings quality.

The formal model of this paper is offered in the hope that it will facilitate discussion of these types of issues in a rigorous, general framework. We believe that the model provides a necessary first step in this direction by providing a vocabulary and a formal setting that encompasses a wide variety of concerns. The usefulness of this framework is illustrated by the examples, which highlight how the implications of

${ }^{39} \mathrm{Of}$ course, there is no reason to rule out the possibility that $D^{* *}>D^{*}$, or that $D^{* *}<D^{\prime}$. 
several different accounting issues for real decisions can be brought together in one model.

We recognize that the framework is still not general enough to capture potentially important aspects of the interaction between accounting and real decisions. For example, it does not model the underlying nature of the information asymmetry between corporate insiders and (actual and potential) shareholders to explain why book income enhances shareholder value. It does not place the firm's decisions within a context that recognizes that US public corporations compete against unincorporated US businesses and foreign companies, including foreign multinationals; nor does the model integrate the type of legitimate tax planning and earnings management stressed here with the use of aggressive — and possibly illegal—-tax shelters, outright evasion, and fraudulent financial reporting. Our hope is that the framework provided here will be used to contextualize empirical work and inform policy analysis and that it can be extended to encompass these additional concerns.

Acknowledgements We are grateful for comments from Alan Auerbach, Dhammika Dharmapala, Jana Smith Raedy, Leslie Robinson, Terry Shevlin, Ro Verrecchia, Ryan Wilson, and participants at the Conference on the Intersection of Financial Accounting and Tax Policy, held in Washington, D.C. and at the NBER in Cambridge, MA. We thank Joanne Hsu, Jenna Meints, and Kevin Markle for research assistance.

\section{References}

Armstrong, C., Guay, W., \& Weber, J. (2010, forthcoming). The role of information and financial reporting in corporate governance and contracting. Journal of Accounting and Economics. doi:10.1016/j.jacceco.2010.10.001.

Auerbach, A. (1986). The dynamic effect of tax loss asymmetries. Review of Economic Studies, 53, 205225.

Barth, M., Beaver, W., \& Landsman, W. (1998). Relative valuation roles of equity book value and net income as a function of financial health. Journal of Accounting \& Economics, 25, 1-34.

Beyer, A., Cohen, D., Lys, T., \& Walther, B. (2010, forthcoming). The financial reporting environment: Review of the recent literature. Journal of Accounting and Economics. doi:10.1016/j.jacceco. 2010.10.003.

Blouin, J., \& Krull, L. (2009). Bringing it home: a study of the incentives surrounding the repatriation of foreign earnings under the American jobs creation act of 2004. Journal of Accounting Research, 47(4), 1027-1059.

Blouin, J., \& Tuna, I. (2006). Tax contingencies: cushioning the blow to earnings? Working paper, Wharton School at the University of Pennsylvania.

Blouin, J., Gleason, C., Mills, L., \& Sikes, S. (2007). Changes in tax reserves in anticipation of FIN 48. Working paper, University of Pennsylvania.

Blouin, J., Krull, L., \& Robinson, L. (2009). Is US multinational intra-firm dividend policy influenced by capital market incentives? Working paper, University of Pennsylvania.

Chen, Q., Mittendorf, B., \& Zhang, Y. (2007). Endogenous accounting discretion and its implications for bias and information content of accounting reports. Working paper, Duke University.

Collins, J., Hand, J., \& Shackelford, D. (2001). Valuing deferral: the effect of permanently reinvested foreign earnings on stock prices. In J. Hines (Ed.), International taxation and multinational activity (pp. 143-166). Chicago: University of Chicago Press.

Crocker, K., \& Slemrod, J. (2005). Corporate tax evasion with agency costs. Journal of Public Economics, 89(9-10), 1593-1610.

Dechow, P., Ge, W., \& Schrand, C. (2010). Understanding earnings quality: a review of the proxies, their determinants and their consequences. Journal of Accounting \& Economics, 50(2-3), 344-401.

Dhaliwal, D., Frankel, M., \& Trezevant, R. (1994). The taxable and book income motivations for a LIFO layer liquidation. Journal of Accounting Research, 32(2), 278-289. 
Dhaliwal, D., Gleason, C., \& Mills, L. (2004). Last-chance earnings management: using the tax expense to meet analysts' forecasts. Contemporary Accounting Research, 21(2), 431-460.

Dharmapala, D., Foley, C., \& Forbes, K. (2009). Watch what I do, not what I say: the unintended consequences of the homeland investment act. NBER Working paper No. 15023.

Drucker, J. (2009). Titans vow overseas tax fight: Obama Administration plan would hit biggest companies hardest. Wall Street Journal, April 22.

Dyreng, S. (2009). The cost of private debt covenant violation. Working paper, Duke University.

Engel, E., Erickson, M., \& Maydew, E. (1999). Debt-equity hybrid securities. Journal of Accounting Research, 37(2), 249-274.

Erickson, M., Hanlon, M., \& Maydew, E. (2004). How much will firms pay for earnings that do not exist? Evidence of taxes paid on allegedly fraudulent earnings. The Accounting Review, 79(2), 387-408.

Faulkender, M., \& Petersen, M. (2009). Investment and capital constraints: repatriations under the American jobs creation act. Working paper, Northwestern University.

Fischer, P., \& Verrecchia, R. (2000). Reporting bias. The Accounting Review, 75(2), 229-245.

Francis, J., \& Reiter, S. (1987). Determinants of corporate pension funding strategy. Journal of Accounting and Research, 9(1), 35-59.

Frankel, M., \& Trezevant, R. (1994). The year-end LIFO inventory purchasing decision: an empirical test. The Accounting Review, 69(2), 382-398.

Frischmann, P., Shevlin, T., \& Wilson, R. (2008). Economic consequences of increasing the conformity in accounting for uncertain tax benefits. Journal of Accounting \& Economics, 46(2-3), 261-278.

Fullerton, D. (1984). Which effective tax rate? National Tax Journal, 37(1), 23-41.

Graham, J. (1996). Debt and the marginal tax rate. Journal of Financial Economics, 41(1), 41-73.

Graham, J., \& Mills, L. (2008). Using tax return data to simulate corporate marginal tax rates. Journal of Accounting \& Economics, 46(2-3), 366-388.

Graham, J., Hanlon, M., \& Shevlin, T. (2009). Real effects of accounting rules: evidence from multinational firms' investment location and profit repatriation decisions. Working paper, Duke University.

Graham, J., Raedy, J., \& Shackelford, D. (2011). Research in accounting for income taxes. Working paper, University of North Carolina, Chapel Hill, NC.

Hanlon, M. (2005). The persistence and pricing of earnings, accruals, and cash flows when firms have large book-tax differences. The Accounting Review, 80, 137-166.

Hanlon, M., \& Heitzman, S. (2010). A review of tax research. Journal of Accounting \& Economics, 50(23), 127-178.

Hanlon, M., \& Maydew, E. (2008). Book-tax conformity: implications for multinational firms. Working paper, University of Michigan, Ann Arbor, MI.

Hanlon, M., \& Shevlin, T. (2005). Book-tax conformity for corporate income: an introduction to the issues. In J. Poterba (Ed.), Tax policy and the economy 19 national bureau of economic research (pp. 101134). Cambridge: MIT Press.

Hanlon, M., Laplante, S., \& Shevlin, T. (2005). Evidence from the possible information loss of conforming book income and taxable income. The Journal of Law \& Economics, 48(92), 407-442.

Healy, P. (1985). The effect of bonus schemes on accounting decisions. Journal of Accounting \& Economics, 7, 85-107.

Healy, P., \& Wahlen, J. (1999). A review of the earnings management literature and its implications for standard setting. Accounting Horizons, 13(4), 365-383.

Hodder, L., McAnally, M., \& Weaver, C. (2003). The influence of tax and nontax factors on banks' choice of organizational form. The Accounting Review, 78(1), 297-325.

Hunt, A., Moyer, S., \& Shevlin, T. (1996). Managing interacting accounting measures to meet multiple objectives: a study of LIFO firms. Journal of Accounting \& Economics, 21(3), 339-374.

Kothari, S. (2001). Capital markets research in accounting. Journal of Accounting \& Economics, 31(1-3), 105-231.

Krull, L. (2004). Permanently reinvested foreign earnings, taxes and earnings management. The Accounting Review, 79(3), 745-767.

Lev, B., \& Nissim, D. (2004). Taxable income, future earnings, and equity values. The Accounting Review, 79(4), 1039-1074.

Matsunaga, S., Shevlin, T., \& Shores, D. (1992). Disqualifying dispositions of incentive stock options: tax benefits versus financial reporting costs. Journal of Accounting Research, 30, 37-76 (Supplement).

Maydew, E., Schipper, K., \& Vincent, L. (1999). The impact of taxes on the choice of divestiture method. Journal of Accounting \& Economics, 28(2), 117-150.

Mills, L. (1998). Book-tax differences and Internal Revenue Service adjustments. Journal of Accounting Research, 36(2), 343-356. 
Mills, L., Robinson, L., \& Sansing, R. (2010). FIN 48 and tax compliance. The Accounting Review, 85(5), 1721-1742.

Neubig, T. (2006). Where's the applause? Why most corporations prefer a lower rate. Tax Notes, 483.

Raedy, J., Seidman, J., \& Shackelford, D. (2010). Book-tax differences: which ones matter to equity investors? Working paper, University of North Carolina.

Robinson, L. (2010). Do firms incur costs to avoid reducing pre-tax earnings? Evidence from the accounting for low-income housing tax credits. The Accounting Review, 85(2), 637-669.

Sankar, M. R., \& Subramanyam, K. R. (2001). Reporting discretion and private information communication through earnings. Journal of Accounting Research, 39(2), 365-386.

Scholes, M., \& Wolfson, M. (1992). Taxes and business strategy: a planning approach. Englewood Cliffs: Prentice-Hall.

Shackelford, D., \& Shevlin, T. (2001). Empirical research in accounting: a discussion. Journal of Accounting \& Economics, 31(1-3), 321-387.

Slemrod, J. (2001). A general model of the behavioral response to taxation. International Tax and Public Finance, 79(3), 119-128.

Stocken, P., \& Verrecchia, R. (2004). Financial reporting system choice and disclosure management. The Accounting Review, 79(4), 1181-1203. 